\title{
Effects of variable subduction \\ components on island arc and rear-arc magma compositions: an example from the Kermadec arc
}

\author{
BORA MYEONG, KARSTEN M. HAASE AND MARCEL \\ REGELOUS
}

GeoZentrum Nordbayern, Friedrich-Alexander-Universität

(FAU) Erlangen-Nürnberg

Presenting Author: bora.myeong@fau.de

The Kermadec subduction system $\left(25-39^{\circ} \mathrm{S}\right)$ in the southwestern Pacific has formed in response to the westward subduction of the Pacific Plate beneath the Indian-Australian Plate. The system is an important natural laboratory because the key components of subduction-related magmatism like the structures of the upper and lower plates, and the sediment thickness change along the Kermadec arc (KA; Monowai to Clark volcano). Here, we present new major and trace element and $\mathrm{Pb}-\mathrm{Sr}-\mathrm{Nd}-\mathrm{Hf}$ isotope data for arc front and rear-arc volcanoes, aiming to better define the processes and effects of variable tectonic setting and subduction input on the magma generation and evolution.

Based on trace element ratios and isotope compositions, we divide the KA volcanoes into four groups. In the northernmost sector (north of $30^{\circ} \mathrm{S}$ ) the lavas have the lowest $\mathrm{Pb}$ and $\mathrm{Sr}$ isotope ratios (Group 1), the lavas between 30 and $32.5^{\circ} \mathrm{S}$ show the lowest value of fluid proxies (Group 2), the arc volcanoes between 32.5 and $36^{\circ} \mathrm{S}$ have the highest $\mathrm{Pb}$ isotope composition (Group 3), and the volcanoes south of $36^{\circ} \mathrm{S}$ have the highest value of fluid proxies (Group 4). The lavas in the different groups show variable mixing between mantle and slab components, thus lying along separate mixing lines. The KA front volcanoes have similar fractionation trends and show comparable degrees of mantle depletion, whereas the rear-arc lavas are less depleted in fluid-immobile elements. The arc front lavas show a stronger influence by slab components than the rear-arc lavas. Our new data suggest that the geochemical characteristics of KA lavas are controlled within segments by interaction of distinct components of the mantle wedge and the slab. Specifically, Group 1, 2 and 4 are affected by fluids from pelagic sediments and altered oceanic crust while Group 3 represent a mixture of sediment and components from the partially subducted basaltic Hikurangi Plateau. 